Relations industrielles

Industrial Relations

\title{
Gouvernment as Employer, by Sterling D. Spero, Carbondale and Edwardsville, Southern Illinois University Press, Feffet \& Simons, Inc., London and Amsterdam, 1972, 497 pp.
}

\section{Jean Boivin}

Volume 28, numéro 2, 1973

URI : https://id.erudit.org/iderudit/028413ar

DOI : https://doi.org/10.7202/028413ar

Aller au sommaire du numéro

Éditeur(s)

Département des relations industrielles de l'Université Laval

ISSN

0034-379X (imprimé)

1703-8138 (numérique)

Découvrir la revue

Citer ce compte rendu

Boivin, J. (1973). Compte rendu de [Gouvernment as Employer, by Sterling D. Spero, Carbondale and Edwardsville, Southern Illinois University Press, Feffet \& Simons, Inc., London and Amsterdam, 1972, 497 pp.] Relations industrielles / Industrial Relations, 28(2), 441-442. https://doi.org/10.7202/028413ar

Tous droits réservés @ Département des relations industrielles de l'Université Laval, 1973
Ce document est protégé par la loi sur le droit d'auteur. L’utilisation des services d'Érudit (y compris la reproduction) est assujettie à sa politique d'utilisation que vous pouvez consulter en ligne.

https://apropos.erudit.org/fr/usagers/politique-dutilisation/ 
guère de preuves de l'existence de courbes traditionnelles en $\ll u \otimes$ des coûts moyens: les données disponibles semblent démontrer une baisse constante, bien que peu sensible, de la moyenne des coûts.

L'auteur recommande que l'utilisation des hôpitaux pour vieillards devrait être examinée attentivement et suggère qu'il serait peut-être plus avantageux de pouvoir compter sur des hôpitaux affectés aux soins des personnes âgées. Il en est de même pour un réseau plus diversifié d'hôpitaux régionaux qui devrait comprendre des hôpitaux spécialisés en soins intensifs, et d'autres, en soins infirmiers.

Même si l'analyse des déterminants des coûts des soins hospitaliers présentée par l'auteur est loin d'être complète, cette étude n'en demeure pas moins une pièce importante à rajouter à la collection de recherches dans le domaine de l'économie des soins de la santé.

\section{Jean BOIVIN}

Public Employment Bibliography, by Robert V. Pezdek, Bibliography Series no 11, Ithaca, N.Y., Cornell University, New York State School of Industrial and Labor Relations, 1973, $185 \mathrm{p}$.

Public Employment Bibliography by Robert V. Pezdek is a continuation of the series on public employment which began with Richard Peqnetter's Public Employment Bibliography in 1971. The titles included in this work are primarily from the period between late 1970 and late 1972. There are also entries for materials from before this period which were not available to the compiler of the first bibliography.

The design of the bibliography is constructed so that the user can rapidly locate materials which are of interest to him in a specific category or a subject of public employment. The entries are arranged in categories by governmental level and by occupational groupings. Hence, we find the following categories: Public Employees in General, Federal Government Employees, State Government Employees, Local Government Employees, Primary and Secondary Education - Professional Employees, Primary and Secondary Education - Non
Professional Employees, Employees in Higher Education, Library Employees, and Health Care Employees. The categories are further subdivided by subjetcs such as: Collective Bargaining - General, Collective Bargaining and the Law, Other Legislative Problems, Empolyee Organizations, Unit Determination, Subject Matter of Negotiations, Contract Administration and Grievance Procedures, Strikes and Dispute Settlement, Impact of Collective Bargaining on Administration, Behavioral and Attitudinal Studies, and Bibliographies.

In this rapidly growing field of public sector labor relations, this work comes as a very useful tool which permits to localize easily the vast amount of literature on the subject. The arrangement of the bibliography is very simple and the scope of the literature covered is quite extensive. All those who are interested in public sector labor relations should immediately get Robert V. Pezdek's Public Employment Bibliography.

Jean BOIVIN

Government as Employer, by Sterling D. Spero, Carbondale and Edwardsville, Southern Illinois University Press, Feffet \& Simons, Inc., London and Amsterdam, 1972, 497 pp.

Ce livre est une reproduction intégrale du même volume publié par Spero en 1948 et qui devint un classique des relations du travail dans le secteur public au cours des années soixante. Il est un des ouvrages de la collection Masterworks in Industrial Relations éditée par Albert A. Blum qui se spécialise dans la reproduction d'ouvrages célèbres en relations industrielles.

Même si ce livre date de près de vingt-cinq ans, il faut reconnaître à Spero d'avoir été l'un des premiers en Amérique du Nord à prévoir la syndicalisation des employés du secteur public et le développement de la négociation collective. La pertinence avec laquelle il traite des questions importantes comme la souveraineté, le droit d'association et le droit de grève de même que l'action politique des employés du secteur public fait de cet ouvrage un outil encore précieux de nos jours. En fait, toute l'argumenta- 
tion contemporaine qui a servi à justifier la transposition des mécanismes de négociation collective au secteur public avait déjà été développée par Spero dès 1948 , même si à cette époque celui-ci n'était pas pris au sérieux. C'est sans doute en hommage à cette clairvoyance et à l'actualité des questions traitées par Spero que la collection Masterworks in Industrial Relations a réédité ce volume.

Ce livre est également un recueil d'études de cas d'une valeur historique inestimable: qu'on pense aux luttes pour l'obtention de la journée de huit heures menées par les employés du gouvernement fédéral des Etats-Unis vers 1860; aux premières associations d'employés des postes et aux fameuses 《gag rules》 édictées par Theodore Roosevelt en 1902 qui empêchaient les fonctionnaires fédéraux d'essayer de se procurer des avantages individuels ou collectifs autrement que par l'entremise de leurs chefs de section; à la fameuse grève des policiers de Boston en 1919 dans laquelle le gouverneur de l'Etat du Massachusetts, Calvin Coolidge, avait prononcé la célèbre phrase «There is no right to strike against the public safety by anybody, anywhere at any time $\gg$.

Enfin dans une dernière partie, Spero traite de certaines questions particulières telles les problèmes inhérents à la négociation collective, les clauses de sécurité syndicale, l'arbitrage, la détermination des salaires et l'affiliation des fonctionnaires au mouvement syndical.

Pour ceux qui n'auraient pas eu l'occasion de lire la première édition de cet ouvrage et qui s'intéressent aux relations du travail dans le secteur public, Government as an Employer est un livre de référence de première importance.

Jean BOIVIN

\section{PUBLICATIONS RECENTES RECENT PUBLICATIONS}

\section{Généralités}

《L'autogestion yougoslave» par Jean Genest, L'Action nationale, (Montréal, vol. LXII, no 4, dec. 1972, pp. 324-345. «Dix-septième session de la Conférence générale » Chronique de l'Unesco, $(\mathrm{Pa}$ ris), vol. XIX, no 1, janv. 1973, 55 p. «Manuscript Sources in American Radicalism » by Bernard K. Johnpoll, Labor History, (New York, N.Y.), vol. 14, no 1, Winter 1973, pp. 92-98.

«La responsabilité sociale des entreprises » par T.V. Learson, Professions et entreprises, (Paris), 78e année, no 647, janv. 1973, pp. 18-24.

«New Patterns for Working Time» by Janice Neipert Hedges, Monthly Labor Review, (Washington), vol. 96, no 2, Feb. 1973, pp. 3-9.

«European Workers' Participation in Management 》 by Joseph Mire, Monthly Labor Review, (Washington), vol. 96, no 2, Feb. 1973, pp. 9-16.

«The Origin of the U.S. Department of Labor» by Jonathan Grossman, Monthly Labor Review, (Washington), vol. 96, no 3, March 1973, pp. 3-8.

«What's Wrong with Work in America?
A Review Essay by Harold Wool, Monthly Labor Review, (Washington), vol. 96, no 3, March 1973, pp. 38-45. «Poverty in Canada: The Croll Report and its Critics » by Thelma McCormack, The Canadian Review of Sociology and Anthropology/La Revue Canadienne de Sociologie et d'Anthropologie, (Toronto), vol. 9, no 4, nov. 1972, pp. 366-373.

«Mobility: A Way of Life» by Joan L. Pogalies, The Personnel Administrator, (Ohio), vol. 18, no 1, Jan.-Feb. 1973, pp. 17-18.

«Standard of Living and the Life Cycle Concept 》 by B.W. Mayhew, Personnel Journal, (Swarthmore, Pa.), vol. 52, no 1, Jan. 1973, pp. 27-31.

«Worker Participation in Sweden 》 by Lynda King Taylor, Industrial and Commercial Training, (London, England), vol. 5, no 1, Jan. 1973, pp. 6-16. «The Values and Value Systems of Governmental Executives \ by Andrew F. Sikula, Public Personnel Management, (Chicago, Ill.), vol. 2, no 1, Jan.Feb. 1973, pp. 9-16.

«Worker Exploitation Dons a New Face in Haiti by Michael D. Boggs and 